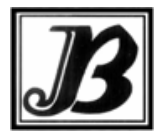

J. bio-sci. 20: 109-114, 2012

ISSN 1023-8654

http://www.banglajol.info/index.php/JBS/index

\title{
ANALYSIS ON NUTRIENT CONTENTS OF DIFFERENT PARTS OF PUFFER FISH (TETRAODON CUTCUTIA) AND IT'S TOXICITY
}

\author{
M Moyen Uddin PK' ${ }^{1}$, Subodh Kumar Sarkar², Nurul Absar* \\ Department of Biochemistry and Biotechnology, University of Science and Technology Chittagong (USTC), \\ Foy's Lake, Chittagong-4202, Bangladesh \\ 1Department of Biochemistry and Molecular Biology, University of Rajshahi, Rajshahi-6205, Bangladesh \\ 2Department of Biochemistry and Biotechnology, Khwaja Yunus Ali University, Enayetpur, Chowhali, \\ Sirajgonj-6751, Bangladesh
}

\begin{abstract}
Context: Puffer fish (Tetraodon patoca) contains a potent neurotoxin, tetrodotoxin (TTX) which specially blocks the voltage-gated sodium channels on the surface of nerve membranes. Although the fish as a diet produces sever toxicity in human but no such data are available on its nutrient contents. Mostly the poor people of our country some times eat this fish as a food and six peoples of a family died by its poisoning in Potuakhali, Bangladesh (2001).Our present data clearly indicated that the fish is a high source of oil and protein, and also significant amount of ash. Further, liver and head were the highest sources of toxin but dorsal and tail portion of the fish contained less amount of toxin.

Objectives: Compare the nutritional composition of different parts: Dorsal, Ventral including liver, Head and Tail of Puffer fish as well as analysis of their toxic properties.

\section{Materials and Methods:}

In this study, nutritional composition such as moisture, ash, protein, oil, polysaccharides, free sugar and mineral contents such as phosphorous, calcium and iron of four parts, namely Dorsal, Ventral including liver, Tail and Head of Puffer fish were analyzed by standard methods and toxic effects of its different parts were determined using brine shrimp lethality bioassay.

Results: This study gives detailed information about the nutrients: moisture, ash, protein, oil, polysaccharides and free sugar content of four different parts (Dorsal, Ventral including liver, Tail and Head) of experimental fish which were explained in the result and discussion section. It can be concluded from the results that the puffer fish may be used as a good sources of oil, protein and minerals if proper precaution is taken to remove the toxin from different parts of the fish. In relation to toxicity against brine shrimp nauplii, the different parts of the fish can be arranged as follows-Liver $>$ Head>Dorsal $>$ Tail.

Conclusion: The puffer fish might be used as a food due to its high content of oil, protein and minerals. Considering the toxicity, liver and head portion might be discarded completely, but the dorsal and the tail portion may be used due to its low toxicity.
\end{abstract}

Key words: Puffer fish, Nutritional composition, Toxicity.

\section{Introduction}

Puffer fish is mainly found in Indo-Pacific Ocean. In Bangladesh, it is mainly found in the region of Sundarban sea water and in the Bay of Bengal. So far, three local species were identified under two genera as shown in Figure 1: (Chelonodon fluviatilis (Hamilton) (A), Chelonodon patoca (Hamilton) (B) and Tetraodon patoca (C). It is widely knows as the blow fish because they can swell up their bellies until they resemble a ball.

* Corresponding author E-mail: nurul_ustc@yahoo.com 
Tetraodon patoca fish is originally thought to be the only source from which TTX could be isolated. Poisoning due to ingestion of toxic Puffer fish had frequently occurred in Japan, and also in Taiwan, Hong Kong, China, Thailand, Singapore, Malaysia, Fuji, Australia, Papua New Guinea, Bangladesh and USA (Reddy and Hayes 1989, Lange 1990). The fish was considered poisonous because they possess a potent neurotoxin, TTX and its analogs which act on site-1 of the voltage-dependent sodium channels of excitable membranes, blocking sodium influx and consequently action potential (Agnew 1984, Catterall 1980). In Bangladesh (16th November 1998), eight people died among 15 victims due to ingestion of puffer fish in Khulna (Zaman et al. 1997). The tetrodotoxin is complex in structure by small molecules and contains guanidium moiety. The guanidium ion is able to enter the cells via the voltage sensitive $\mathrm{Na}+$ channel in human. Paresthesis begins 10-15 minutes after ingestion, usually as tingling of the tongue and inner surface of the mouth. Other common symptoms include vomiting, light headache ness, dizziness, feeling of doom and dizziness. An ascending paralysis develops and death can occur within 6-24 hrs. It was already reported that puffer fish might be consider as nutritious food due to its content of good amount of oil, protein, minerals etc (Hasan 1997). So, in this study we compared the nutrient composition of four different parts of puffer fish including their toxicities using brine shrimp nauplii.

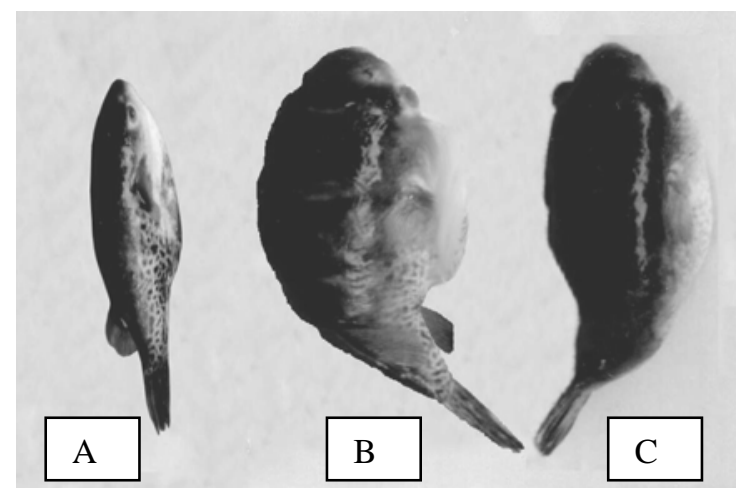

Fig.1. Puffer fishes available in Bangladesh. A - Chelonodon fluviatilis (Hamilton), B- Chelonodon patoca (Hamilton) and C- Tetraodon patoca

\section{Materials and Methods}

Fresh Puffer fishes were collected from the fisherman of Rupsha River, Khulna coastal area, Bangladesh and brought to the Laboratory of Biochemistry and Molecular Biology, University of Rajshahi under freezing condition. After cleaning the stomach, the fish was divided into four parts (Fig. 2). The analysis was performed as soon as possible after collection and the parts are kept separately in deep freeze for experimental purposes, if needed. All the reagents used in the study were of analytical grade. For analytical purposes, all the estimations were performed in duplicate and the mean values were expressed as wet weight basis except cytotoxicity study which was done on dry weight basis.

The moisture and ash contents were determined after extraction of oil using the standard procedure. The different parts of Puffer fish were extracted for recovery of oil from puffer fish with N-hexane, as it was found to be more suitable solvent in our laboratory than other solvents such as Petroleum ether and Diethyl ether using Soxhlet apparatus following the method as reported (Bligh and Dyer 19597). Protein content of the Puffer fish was determined following the Micro-kjeldhal method as reported (Jayaraman 1981). 
Polysaccharide and free sugar contents were determined by the Anthrone method (Dubois et al. 1951). Calcium and iron content were determined by titrimetric and spectrophotometric methods (Bernad and Oser 1965, Vogel 1961), respectively. Phosphorous content was analyzed by the method of Boltz (1958).

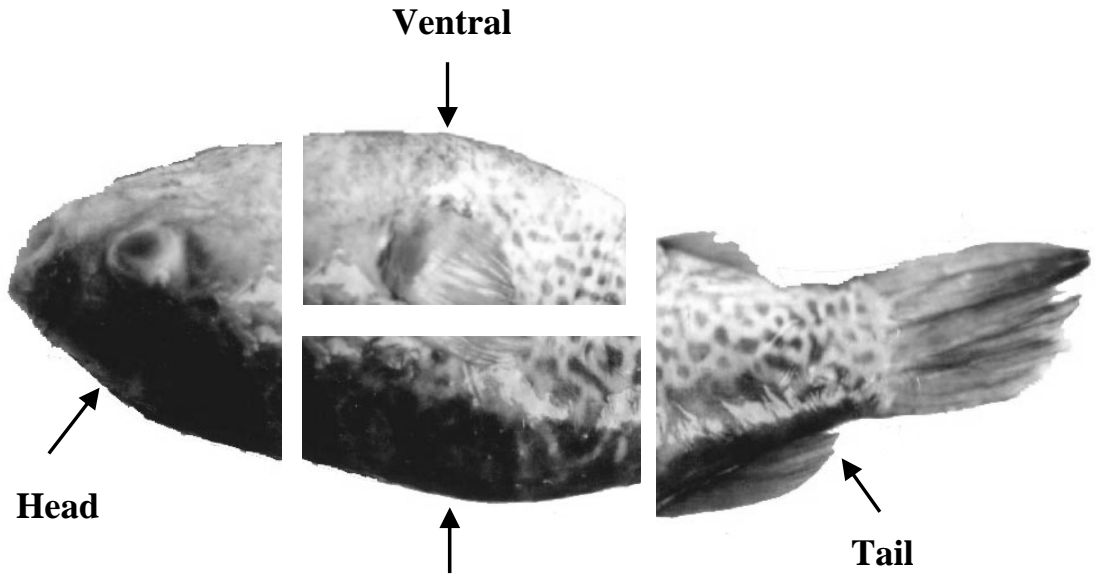

Dorsal

Fig.2. Different parts of the Puffer fish.

Toxicity of different parts of the Puffer fish was analyzed using the egg of the brine shrimp nauplii (Artemia salina $\mathrm{L}$ ). Eggs were placed in one side of a tank divided by a net containing $3.8 \% \mathrm{NaCl}$ solution for hatching while in the other side of the tank, a light source was placed in order to attract the nauplii. Constant oxygen supply was carried out by using aqua-pump. Two days were allowed for the shrimp to hatch and mature as nauplii (Mayer et al. 1982). From the stock solution, samples were prepared using dry powder of the different parts of the Puffer fish separately (5 mg fish powder per $\mathrm{ml}$ distilled water) and 2, 4, 8, 16, 32, and $64 \mu \mathrm{g} / \mathrm{ml}$ were placed in different vials and solution was made up to $1 \mathrm{ml}$ by adding $\mathrm{NaCl}$ solution. Two sets of experiment were done for each concentration and 10 brine shrimps nauplii were taken in each vial. A control experiment was carried out only sea water and 10 brine shrimps nauplii in a vial. After 24 hours of incubation at room temperature, the vials were observed using a magnifying glass and the number of survival in each vial was counted. From the data, the mean percentage of mortality of nauplii was calculated for each concentration.

\section{Results and Discussion}

The Puffer fish collected from the Rupsha River, Khulna, Bangladesh was used in the study. Table 1 summarizes the moisture, ash, protein and oil contents of different parts of Puffer fish. It was found that Head contained the higher amount (54\%) while Ventral contained lowest amount (19\%) of moisture. Further, the 
ash content of dorsal, ventral including liver and tail were found to be similar (8-9\%) while head contains significant amount of ash (4\%). Remarkably, the puffer fish contains significantly higher amount of oil (2149\%) and protein (16-23\%) also. Among the parts examined, ventral including liver contains highest amount of oil as well as protein. The present data clearly indicated that Puffer fish is a very good source of oil and protein.

Table 1. Moisture, ash, oil and protein contents of the different parts of the Puffer fish.

\begin{tabular}{ccccc}
\hline Name of the parts & Moisture (gm\%) & Ash (gm\%) & Oil (gm\%) & Protein (gm\%) \\
\hline Dorsal & $30.94 \pm 0.44$ & $9.1 \pm 0.49$ & $35.6 \pm 2.3$ & $23.39 \pm 1.71$ \\
Ventral including & $19.2 \pm 0.2$ & $8.19 \pm 0.55$ & $48.8 \pm 0.2$ & $23.45 \pm 0.49$ \\
Liver & & & & \\
Tail & $53.63 \pm 0.165$ & $9.25 \pm 0.35$ & $21.25 \pm 1.25$ & $15.62 \pm 1$ \\
Head & $51 \pm 1.5$ & $4.1 \pm 0.1$ & $24.83 \pm 0.37$ & $19.23 \pm 0.95$ \\
\hline
\end{tabular}

Table 2. Amount of polysaccharides and free sugar present in the different parts of the Puffer fish.

\begin{tabular}{ccc}
\hline Name of the parts & Polysaccharides (gm\%) & Free Sugar (gm\%) \\
\hline Dorsal & $0.051 \pm 0.001$ & $0.072 \pm 0.001$ \\
Ventral including Liver & $0.042 \pm 0.0025$ & $0.0625 \pm 0.0005$ \\
Tail & $0.0675 \pm 0.0025$ & $0.077 \pm 0.002$ \\
Head & $0.048 \pm 0.001$ & $0.0645 \pm 0.0005$ \\
\hline
\end{tabular}

Table 3. Mineral contents of the different parts of the Puffer fish.

\begin{tabular}{cccc}
\hline Name of the parts & Calcium $(\mathbf{m g} \%)$ & Phosphorous $(\mathbf{m g} \%)$ & Iron $(\mathbf{m g} \%)$ \\
\hline Dorsal & $40.5 \pm 2.5$ & $52.5 \pm 3.5$ & $46.5 \pm 0.5$ \\
Ventral including Liver & $14.0 \pm 2.0$ & $21.0 \pm 2.0$ & $32.0 \pm 1.0$ \\
Tail & $39.5 \pm 1.5$ & $47.5 \pm 0.5$ & $48.5 \pm 0.5$ \\
Head & $166.5 \pm 4.5$ & $178.5 \pm 2.5$ & $101.5 \pm 0.5$ \\
\hline
\end{tabular}

As shown in Table 2, the puffer fish is a very poor source of carbohydrate: polysaccharide $(0.048-0.068 \%)$ and free sugar $(0.063-0.077 \%)$. Table 3 summarizes the minerals: calcium, phosphorous and iron content of Puffer fish. Overall findings indicated that the Puffer fish is a good sources of all the three minerals examined.

Among the parts examined, Head portion contains significantly the higher amount of all the experimental minerals while Tail and Dorsal parts contain more or less same amount of the minerals. It is not clear at this moment while all the parts-head, tail and dorsal contain higher amount of iron than ventral including liver. This experiment was repeatedly done in our laboratory but almost similar results were obtained. It may mention that ventral including liver portion also contains some flesh in addition to the liver. 
Following the procedure of Mayer et al. (1982), the lethality of all the parts of puffer fish were examined against brine shrimp nauplii and the results have been summarized in the Table 4.

Table 4. Effect of different parts of Puffer fish extract on the mortality of brine shrimp nauplii after 24 hours

\begin{tabular}{|c|c|c|c|c|c|c|}
\hline Sample & Conc. $\mu \mathrm{g} / \mathrm{ml}$ & Log Conc. & $\begin{array}{l}\text { No. of } \\
\text { Nauplii }\end{array}$ & $\begin{array}{c}\text { No. of } \\
\text { Nauplii } \\
\text { death }\end{array}$ & $\begin{array}{c}\% \text { of } \\
\text { mortality }\end{array}$ & $\mathrm{LC}_{50}$ \\
\hline \multirow{6}{*}{ Dorsal } & 2 & 0.301 & 15 & 1 & 6.66 & \multirow{6}{*}{1.30} \\
\hline & 4 & 0.602 & 15 & 3 & 20.0 & \\
\hline & 8 & 0.903 & 15 & 5 & 33.33 & \\
\hline & 16 & 1.20 & 15 & 7 & 46.66 & \\
\hline & 32 & 1.50 & 15 & 9 & 60.0 & \\
\hline & 64 & 1.80 & 15 & 11 & 73.33 & \\
\hline \multirow{6}{*}{$\begin{array}{l}\text { Ventral } \\
\text { including } \\
\text { Liver }\end{array}$} & 2 & 0.301 & 15 & 2 & 13.33 & \multirow{6}{*}{0.75} \\
\hline & 4 & 0.602 & 15 & 5 & 33.33 & \\
\hline & 8 & 0.903 & 15 & 9 & 60.0 & \\
\hline & 16 & 1.20 & 15 & 11 & 73.33 & \\
\hline & 32 & 1.50 & 15 & 12 & 80.0 & \\
\hline & 64 & 1.80 & 15 & 13 & 90.0 & \\
\hline \multirow{6}{*}{ Tail } & 2 & 0.301 & 15 & 1 & 6.66 & \multirow{6}{*}{1.45} \\
\hline & 4 & 0.602 & 15 & 2 & 13.33 & \\
\hline & 8 & 0.903 & 15 & 4 & 26.67 & \\
\hline & 16 & 1.20 & 15 & 6 & 40.0 & \\
\hline & 32 & 1.50 & 15 & 8 & 53.33 & \\
\hline & 64 & 1.80 & 15 & 10 & 66.67 & \\
\hline \multirow{6}{*}{ Head } & 2 & 0.301 & 15 & 2 & 13.33 & \multirow{6}{*}{0.90} \\
\hline & 4 & 0.602 & 15 & 4 & 26.66 & \\
\hline & 8 & 0.903 & 15 & 7 & 46.67 & \\
\hline & 16 & 1.20 & 15 & 9 & 60.0 & \\
\hline & 32 & 1.50 & 15 & 10 & 66.67 & \\
\hline & 64 & 1.80 & 15 & 12 & 80.0 & \\
\hline
\end{tabular}

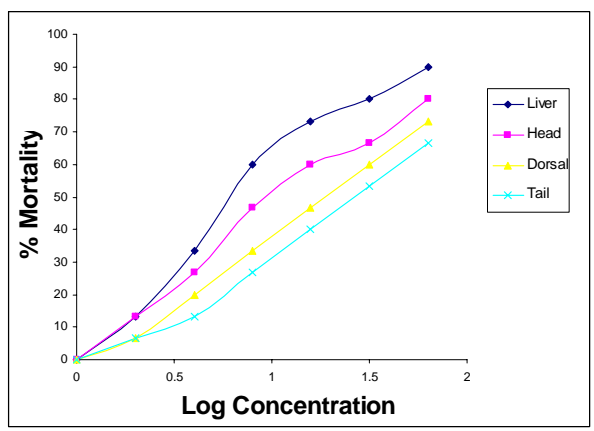

Fig. 3. LC 50 value of different parts of the Puffer fish against brine shrimp nauplii. 
The $\mathrm{LC}_{50}$ obtained from the best-fit line slop was found to be $1.30,0.75,1.45$, and $0.90 \mu \mathrm{g} / \mathrm{ml}$ in water for Dorsal, ventral including liver, tail and head, respectively (Table 4 and Fig. 3). In the control (in sea water only) was not adjusted or corrected as controlled mortality rate was zero in the said period. For determination of the potency of toxicity, we considered the reported value of Vincristine sulphate as standard (Chowdhury et al. 2008). From the present data it might be concluded that ventral including the liver showed the highest toxicity followed by head, and so on in decreasing order and in compare with the positive control (Vincristine sulphate as standard) the cytotoxicity exhibited by the crude water extract of the different experimental parts show less potent, but indicates the presence of more higher concentration of toxic compounds in liver and head than the other parts.

This study gives clear information on the more toxic portion of puffer fish and at the same time also presence of higher amount of two major nutrients- oil and protein as well as minerals.

\section{Acknowledgement}

The author would like to thank the University Grants Commission for financial grant to Professor Nurul Absar to carry out the project. The authors also express heartfelt thanks to the Chairman, Department of Biochemistry and Molecular Biology, Rajshahi University for giving permission to use the Protein Engineering Laboratory.

\section{References}

Agnew WS. 1984. Voltage-regulated sodium channel molecules. Annu Rev Physiol 46, 517 - 530. http://dx.doi.org/10.1146/annurev.ph.46.030184.002505

Bernad Oser L. 1965. Hawk's Physiological Chemistry, 14 $4^{\text {th }}$ ed. McGraw Hill Book Company, New York, 1264 pp.

Bligh EG, Dyer WJ. 1959. Total lipid extraction and purification. Can J Biochem Physio 37, 911. http://dx.doi.org/10.1139/059-099

Boltz DF.1958. The Colorimetric determination of non-metals, Inter Science Pub. Inc., New York, USA.

Catterall WA.1980. Neurotoxins that act on voltage-sensitive sodium channels in excitable membranes. Annu Rev Pharmacol Toxicol 20, 15-43. http://dx.doi.org/10.1146/annurev.pa.20.040180.000311

Chowdhury SA, Islam J, Rahaman MM, Rahman MM, Rumzhum NN, Sultana R, Parvin MN. 2008. Cytotoxicity, Antimicrobial and Antioxidant Studies of the Different Plant Parts of Mimosa Pudica. S J Pharm Sci 1(1\&2), 80-84.

Dubois M, Gilles K, Hamiton JK, Rebers P, Smith F.1951. A colorimetric method for the determination of sugars. Nature 168-167.

Hasan MS, M.Sc. Thesis. 1997. Biochemical analysis and isolation, purification and characterization of two toxic compounds and a protein from Potca fish (Tetraodon patoca). Department of Biochemistry and Molecular Biology, University of Rajshahi, Bangladesh.

Jayaraman J. 1981. Laboratory Manual in Biochemistry, 1'st ed., Wiley Eastern Ltd., New Delhi, 75 pp.

Lange WR.1990. Puffer Fish Poisoning. Am Fam Physician 42, 1029.

Mayer BN, Ferringi NR, Putnam JE, Jacobsen LB, Nicols DE, Mchaughlin JL.1982. Brine shrimp: a convenient general bioassay for active plant constituents. Plant Med 45, 31-34. http://dx.doi.org/10.1055/s-2007-971236

Reddy CS, Hayes AW. 1989. Principles and Methods of Toxicology. In: Hayes AW Raven ed. Food-born toxicants. New York, 2, 81.

Vogel EA. 1961. A Text book of Quantitative Inorganic Analysis, $3^{\text {rd }}$ ed. Longmans (London). p 787 \& 806-808.

Zaman L, Arakawa O, Shimosu A, Onoue Y.1997. Occurrence of paralytic hellfish poison in Bangladeshi freshwater puffers. Toxicon 35, 423-431. http://dx.doi.org/10.1016/S0041-0101\%2896\%2900167-5 